\title{
PENGARUH ORIENTASI KEWIRAUSAHAAN, ORIENTASI PASAR, DAN STRATEGI BISNIS TERHADAP KINERJA BISNIS KULINER
}

\author{
Fidelia Hartato dan Sarwo Edy Handoyo \\ Program Studi Manajemen, Fakultas Ekonomi dan Bisnis \\ Universitas Tarumanagara, Jakarta \\ Email : fideliahartato24@gmail.com
}

\begin{abstract}
The purpose of this study was to determine the effect of entrepreneurial orientation, market orientation, and business strategy on the business performance of MSME in the culinary field in West Jakarta. The sample used in this study were 100 respondents who owned MSMEs in West Jakarta with purposive sampling technique. This research was analyzed using SmartPLS software. The results of this study indicate that entrepreneurial orientation, market orientation, and business strategy have a positive and significant impact on MSME business performance.
\end{abstract}

Keywords: entrepreneurial orientation, market orientation, business strategy, MSME business performance

Abstrak: Penelitian ini bertujuan untuk mengetahui pengaruh dari orientasi kewirausahaan, orientasi pasar, dan strategi bisnis terhadap kinerja bisnis UMKM bidang kuliner di Jakarta Barat. Sampel yang digunakan dalam penelitian ini sebanyak 100 responden pemilik UMKM di Jakarta Barat dengan teknik purposive sampling. Penelitian ini dianalisis dengan menggunakan bantuan software SmartPLS. Hasil penelitian ini menunjukkan orientasi kewirausahaan, orientasi pasar, dan strategi bisnis memiliki pengaruh positif dan signifikan terhadap kinerja bisnis.

Kata kunci: orientasi kewirausahaan, orientasi pasar, kinerja bisnis UMKM

\section{LATAR BELAKANG}

UMKM kuliner terbentuk dan bertahan salah satu alasan dikarenakan online (www.kompas.com). Banyak UMKM yang membentuk usaha kuliner dimulai dari social media dan berbagi platform online lainnya. Salah satu UMKM yang bertahan pada saat pandemi adalah bisnis kuliner. Bisnis kuliner pada saat ini memang sedang merajalela dan juga masih memiliki potensi yang cukup besar apabila seseorang memiliki kreativitas dan inovasi yang tinggi dalam hal pemilihan jenis makanan. Di bidang bisnis kuliner ini tidak akan pernah mati, karena makanan hampir selalu menjadi kebutuhan primer bagi semua orang. Kebanyakan orang bisa menahan nafsu untuk tidak membeli fashion, tetapi kalau untuk makan mereka tidak bisa menahan nafsu karena mereka tidak bisa menahan lapar kalau mereka tidak membeli makanan. Jadi tidak heran lagi jika banyak sekali bisnis kuliner di jaman sekarang. Menurut berita www.cnnindonesia.com UMKM memiliki peranan krusial terhadap perekonomian Indonesia. Tercatat UMKM memberikan kontribrusi sebesar 60,3\% dari total produk domestik bruto (PDB) di Indonesia.

Penelitian yang dilakukan oleh Matchaba-Hove \& Vambe (2014) di Eastern Cape, Afrika Selatan menunjukkan bahwa orientasi kewirausahaan inovatif, proaktif, dan agresifitas kompetitif berpengaruh positif terhadap kinerja usaha, sedangkan pengambilan resiko dan otonomi tidak memberikan pengaruh yang signifikan terhadap kinerja perusahaan. Hasil 
penelitian yang dilakukan oleh Keh et, al. (2007) menunjukkan bahwa orientasi kewirausahaan memiliki pengaruh positif terhadap kinerja usaha. Sedangkan penelitian yang dilakukan oleh Suryaningsih (2018) menggambarkan bahwa orientasi kewirausahaan tidak berpengaruh terhadap kinerja.

Menurut Narver \& Slater (1990) orientasi pasar juga memiliki pengaruh positif terhadap profitabilitas usaha. Penelitian sebelumnya juga menunjukkan adanya pengaruh positif orientasi pasar terhadap kinerja usaha (Protcko \& Dornberger, 2014). Hasil penelitian ini juga dilakukan oleh Anggraini dan Suarjana (2017) menyatakan bahwa orientasi pasar tidak berpengaruh signifikan terhadap kinerja bisnis. Hal tersebut terjadi karena pelaku UMKM masih menghadapi rendahnya penguasaan teknologi dan manajemen serta informasi pasar sebab tingkat pendidikan pelaku UMKM yang belum optimal penguasaan teknologi dan ilmu manajemen.

Penelitian yang dilakukan oleh Suriyanti dan Binangit (2019) menunjukkan bahwa terdapat pengaruh antara strategi bisnis terhadap kinerja bisnis. Hal ini menunjukkan bahwa strategi bisnis dapat menentukan tingkat kinerja usaha. Hasil penelitian ini juga dilakukan oleh Siswaji (2013) yang menyatakan bahwa strategi bisnis tidak berpengaruh secara signifikan terhadap kinerja. Berdasarkan rumusan masalah tersebut, maka tujuan dalam melakukan penelitian ini adalah untuk mengetahui pengaruh orientasi kewirausahaan, orientasi pasar, dan strategi bisnis terhadap kinerja bisnis UMKM bidang kuliner di Jakarta Barat.

\section{KAJIAN TEORI}

\section{Balanced Scorecard}

Blanced scorecard adalah sebuah perencanaan strategik dan sistem manajemen yang sangat sering digunakan di dalam suatu bisnis (Rufaidah, 2012). Menurut Kaplan dan Norton (1992) balanced scorecard memiliki empat perspektif yang digunakan sebagai ukuran untuk menilai kinerja. Pengukuran terhadap empat perspektif yaitu perspektif finansial, perspektif pelanggan, perspektif proses bisnis internal, dan perspektif pembelajaran dan pertumbuhan.

Pertama adalah perspektif finansial menjelaskan pada saat perusahaan melakukan pengkuran secara finansial, maka hal pertama yang harus dilakukan adalah mendeteksi keberadaan industri yang dimilikinya. Kaplan menggolongkan tiga tahap perkembangan industri yaitu: growth, sustain, dan harvest. Growth merupakan tahap awal dalam siklus suatu bisnis. Pada tahap ini diharapkan suatu bisnis memiliki produk baru yang dirasa sangat potensial bagi bisnis tersebut. Sustain dimana tahap ini akan ditariknya investasi atau melakukan investasi kembali dengan mempertimbangkan tingkat pengembalian yang mereka investasikan dan Harvest dimana tahap ini suatu karena pada tahap ini perusahaan tinggal menuai dari investasi yang dilakukan pada tahap-tahap sebelumnya, yang harus dilakukan pada tahap ini adalah perusahaan tidak lagi melakukan investasi, tetapi hanya memelihara supaya perusahaan berjalan dengan baik.

Kedua adalah perspektif pelanggan menjelaskan kecendrungan konsumen terhadap suatu barang atau produk umumnya dilatarbelakangi oleh waktu, kualitas, kinerja dan pelayanan, dan biaya. pandang pelayanan terhadap konsumen, lead time merupakan waktu yang dibutuhkan oleh perusahaan untuk memenuhi keinginan konsumen. Kualitas umumnya diukur dengan ketepatan pada saat pengiriman produk (on time delivery). Selain itu kualitas juga bisa dilihat dalam tingkat produk cacat ketika produk tersebut tiba di tangan konsumen. Kinerja dan pelayanan dapat diukur dari bagaimana produk yang dihasilkan oleh perusahaan dapat memberikan konstribusi untuk menghasilkan nilai tambah bagi konsumennya dan biaya merupakan komponen utama dari harga sebuah produk. Sebelum konsumen memutuskan 
untuk membeli suatu produk, konsumen akan memperhatikan produk yang dijual oleh suatu perusahaan.

Ketiga adalah perspektif proses bisnis internal dimana Pada perspektif ini, manajer mengidentifikasi berbagai proses internal yang sangat penting untuk mencapai tujuan pelanggan dan tujuan finansial perushaan. Budiarti (2005) menyebutkan bahwa dalam perspektif proses bisnis internal para eksekutif mengidentifikasi berbagai proses internal yang harus dikuasai oleh perusahaan.

Keempat adalah perspektif pembelajaran dan pertumbuhan dimana perspektif ini sangat penting bagi perusahaan karena dengan adanya perspektif ini perusahaan bisa terus memperhatikan karyawannya dan meningkatkan pengetahuan karyawannya karena dengan meningkatnya pengetahuan akan meningkatkan pula kemampuan karyawan untuk berpartisipasi tujuan perusahaan.

\section{Resourced Based View (RBV)}

Teori resourced based view (RBV) dikemukakan pertama kali oleh Wenerfelt (1984). Teori RBV melihat adanya sumber daya dan kemampuan yang sangat penting bagi perusahaan. Hal ini terjadi dikarenakan pokok atau dasar dari kemampuan daya saing dan kinerja masingmasing perusahaan. Sumber daya dalam teori RBV berperan sangat penting dalam membantu perusahaan untuk pencapaian kinerja usaha yang lebih tinggi. Terdapat dua jenis sumber daya , yaitu aset berwujud dan aset tidak berwujud. Aset berwujud merupakan benda fisik. Seperti tanah, bangunan, mesin, peralatan dan modal. Sumber daya fisik bisa didapatkan dengan mudah karena bisa dibeli di pasar sehingga memberikan sedikit keuntungan kepada perusahaan dalam jangka panjang karena pesaing dapat memperoleh asset yang sama dengan yang lainnya. Aset tidak berwujud merupakan segala sesuatu yang tidak memiliki fisik namun tetap memberikan manfaat untuk perusahaan. Misalnya hak paten, merek, merek dagang dan kekayaan intelektual adalah semua asset tidak berwujud. Tidak seperti sumber daya fisik, reputasi merek dibangun dalam waktu yang lama dan merupakan sesuatu yang tidak dipunyai oleh perusahaan lain. Sumber daya tak berwujud biasanya berada di dalam perusahaan dan merupakan sumber utama keunggulan kompetitif yang berkelanjutan.

Wenerfelt (1984) menjelaskan bahwa RBV merupakan dasar keunggulan kompetitif terutama terletak pada berwujud dan tidak berwujud. RBV menggambarkan kemampuan perusahaan untuk memberikan keunggulan kompetitif yang berkelanjutan dengan mengelola sumber daya dengan sedemikian rupa shingga apa yang dihasilkan sulit untuk ditiru atau dibuat oleh pesaing, sehingga pada akhirnya menciptakan hambatan kompetisi (Mahoney dan Pandian, 1992).

Kerangka pemikiran pada penelitian ini terdapat pada Gambar 1. di bawah ini :

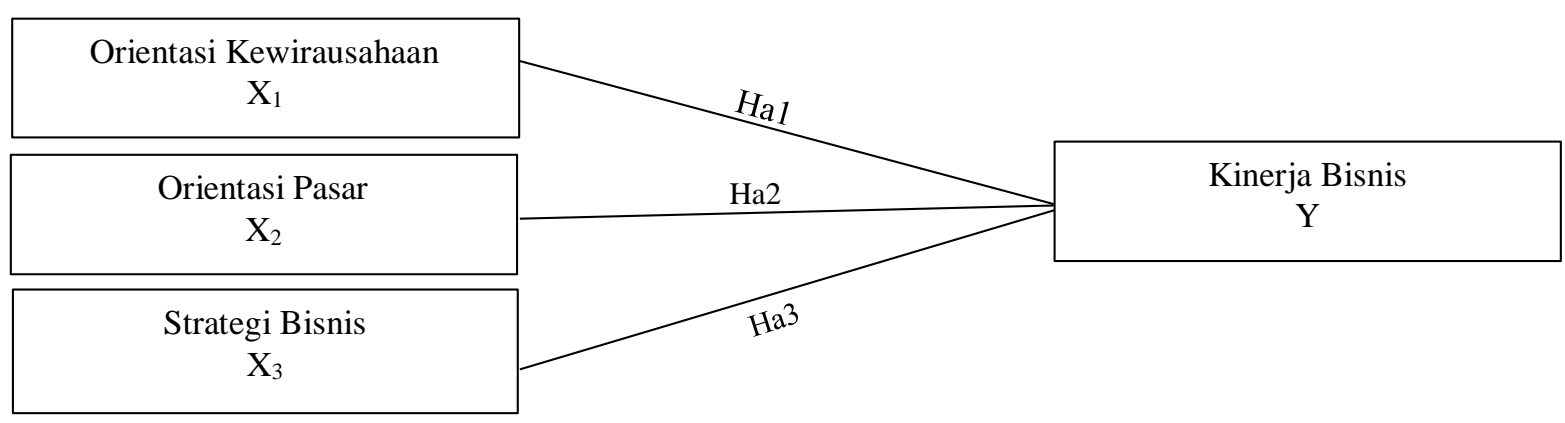

Gambar 1. Kerangka Pemikiran 
Hipotesis dalam penelitian ini berdasarkan Gambar 1. di atas adalah :

Sikap-sikap kewirausahaan dapat menarik perhatian dengan orientasi kewirausahaan dengan adanya kemampuan inovasi, proaktifitas, dan kemampuan mengambil resiko (Looy et al. 2003). Kemampuan Inovasi berhubungan dengan persepsi dan kegiatan terhadap kegiatankegiatan bisnis yang baru dan unik. Proaktifitas dimana seseorang berusaha untuk lebih aktif dalam berwirausaha dan aktif menciptakan inovasi dan kreatifitas dalam membuat produk. Dengan adanya proaktifitas di suatu perusahaan, maka perusahaan telah melakukan kegiatan kewirausahaan yang akan mendorong tingginya kinerja pada suatu perusahaan tersebut (Weerawardena, 2003). Berani mengambil resiko didefinisikan seseorang yang berorientasi pada peluang dalam ketidakpastian konteks keputusan. Fungsi utama dari orientasi kewirausahaan adalah bagaiana mengambil resiko secara optimal (Looy et al. 2003).

Dalam penelitian yang dilakukan oleh Miles et al (2003) menunjukkan pengaruh yang signifikan positif orientasi kewirausahaan terhadap kinerja bisnis. Hal ini pun selaras dengan penelitian yang dilakukan oleh Buli (2017) dan Kevin dan Puspitowati (2020) yang mana hasil penelitian ini menunjukkan bahwa dengan orientasi kewirausahaan yang baik, perusahaan terdorong untuk lebih berani mengambil risiko, berinovasi, dan proaktif dalam menyiapkan strategi untuk melawan pesaing. Sehingga sudah teruji dan dapat dikatakan bilamana orientasi kewirausahaan berpengaruh secara positif dan signifikan terhadap kinerja bisnis.

Sehingga dirumuskan hipotesis yang pertama berupa:

Ha1: Terdapat pengaruh yang signifikan positif orientasi kewirausahaan terhadap kinerja bisnis UMKM bidang kuliner di Jakarta Barat

Menurut Narver dan Slater (1990) orientasi pasar sebagai budaya bisnis yang mampu secara efektif dan efisien menciptakan pelaku karyawan sedemikian rupa sehingga menunjang upaya penciptaan nilai superior bagi para pelanggan. Menurut Tjiptono \& Chandra (2012) menjelaskan bahwa orientasi pasar memiliki tiga dimensi yaitu orientasi pelanggan, orientasi pesaing, dan koordinasi antar fungsi. Orientasi pelanggan adalah perusahaan harus bisa memahami pembeli dan menciptakan nilai yang unggul bagi pembeli secara berkesinambungan. Orientasi pesaing adalah perusahaan harus memahami apa keunggulan dan kelemahan jangka pendek serta kapabilitas dan strategi jangka panjang yang digunakan oleh pesaing dan koordinasi antar fungsi yaitu perusahaan harus memanfaatkan sumber daya secara terkoordinasikan dalam rangka menciptakan nilai unggul bagi pelanggan sasaran.

Hasil ini sesuai dengan penelitian Naver \& Slater (1990) yang menyatakan bahwa orientasi pasar berpengaruh positif dan signifikan terhadap kinerja bisnis. Orientasi pasar berpotensi meningkatkan kinerja bisnis dan orientasi pasar yang terdiri dari tiga komponen perilaku yaitu orientasi pelanggan, orientasi pesaing dan koordinasi fungsional merupakan budaya perusahaan yang membawa pada meningkatnya pasar. Hasil ini juga sesuai dengan penelitian Manahera et al., (2018) dan Sondra dan Widjaja (2020) yang menunjukkan bahwa orientasi pasar memiliki pengaruh yang signifikan terhadap kinerja perusahaan. Perusahaan harus terus meningkatkan kepuasan pelanggan sehingga tujuan perusahaan dapat tercapai.

Sehingga dirumuskan hipotesis yang kedua berupa:

Ha2: Terdapat pengaruh yang signifikan dan positif orientasi pasar terhadap kinerja bisnis UMKM bidang kuliner di Jakarta Barat

Strategi bisnis merupakan sarana untuk mencapai tujuan dan sasaran perusahaan dalam jangka pendek dan jangka panjang. Strategi bisnis meliputi pelaksanaan tindakan yang berkesinambungan dan melakukan alokasi sumber daya sesuai dengan tujuan perusahaan. (Long et al., 2012). Menurut Cheng (2019) menunjukkan bahwa strategi bisnis memiliki 
pengaruh yang signifikan terhadap kinerja bisnis. Menurut David (2010), strategi adalah sarana dengan tujuan jangka panjang yang harus dicapai, mempunyai aksi potensial yang membutuhkan keputusan manajemen puncak dan perusahaan memiliki sumber daya dalam jumlah yang besar. Strategi bisnis dimulai dengan hal yang belum terjadi sehingga diperlukan strategi untuk mempersiapkan hal yang akan terjadi kedepannya.

Menurut David (2010), strategi bisnis adalah alat perusahaan untuk mencapai tujuan jangka panjang. Suatu perusahaan harus bisa berjuang untuk mencapai keuntungan kompetitif secara berkelanjutan maka dari itu perusahaan harus terus beradaptasi untuk berubah dalam eksternal trend dan kapasitas internal, kemampuan, dan sumber daya yang dimiliki oleh perusahaan dan juga perusahaan harus membuat perencanaan efektif, implementasi dan mengevaluasi strategi yang berperan besar dalam perusahaan.

Hasil ini sejalan dengan penelitian yang dilakukan oleh Mustikowati dan Tysari (2014), Puspita (2018), Mahmud \& Anomsari (2011) dan Suci (2011) yang menemukan bahwa strategi bisnis berpengaruh signifikan terhadap kinerja UMKM yang berarti perusahaan telah mempersiapkan kemungkinan terburuk dan terbaiknya di dalam proses bisnis, sehingga apabila terjadi goncangan terhadap bisnisnya, mereka sudah memiliki planning apa yang harus lakukan dan mengambil keputusan secara cepat dan tepat. Hal inilah yang membuat apabila strategi bisnis sudah direncanakan oleh manajemen maka akan berpengaruh terhadap kinerja bisnis juga.

Ha3: Terdapat pengaruh yang positif dan signifikan strategi bisnis terhadap kinerja bisnis UMKM bidang kuliner di Jakarta Barat

\section{METODOLOGI}

Dalam penelitian ini menggunakan desain penelitian kausal untuk menguji pengaruh variabel independen terhadap variabel dependen. Desain penelitian disusun untuk meneliti adanya hubungan sebab-akibat antar variabel. Dimana variabel independent dalam penelitian ini adalah orientasi kewirausahaan, orientasi pasar dan strategi bisnis dan variabel dependen yaitu kinerja bisnis.

Populasi dalam penelitian pemilik UMKM bidang kuliner di Jakarta Barat. Teknik pemilihan sampel yang digunakan dalam penelitian ini adalah purposive sampling dengan metode non-probability sampling. Sampel yang digunakan dalam penelitian ini adalah 100 pemilik UMKM bidang kuliner di Jakarta Barat dengan menggunakan kuisioner.

Variabel yang digunakan dalam penelitian ini terdiri atas variabel dependen dan variabel independent. Dimana variabel independent adalah orientasi kewirausahaan, orientasi pasar, dan strategi bisnis dan variabel dependen adalah kinerja bisnis. Masing-masing variabel memiliki beberapa indikator seperti variabel orientasi kewirausahaan (Buli, 2016) memiliki 11 indikator yaitu konsep "pengambil resiko" di perusahaan, mengambil resiko yang diperhitungkan dengan ide-ide baru, eksplorasi pada eksperimen peluang di pasar, aktif memperkenalkan peningkatan dan inovasi, kreatif dalam metode operasinya, selalu mencari cara baru untuk melakukan sesuatu, insiatif dalam setiap situasi, mengidentifikasi peluang, kompetitif, pendekatan agresif dengan pesaing pasar, dan membatalkan kompetisi sebaik mungkin. Variabel orientasi pasar (Buli, 2016) memiliki 4 indikator yaitu kepuasan pelanggan, kebutuhan pelanggan, keunggulan kompetitif, dan menciptakan nilai yang lebih besar bagi pelanggan. Variabel strategi bisnis (Cavusgil and Zou (1994), Kim et al. (2008), dan Murray et al.,(1995)) memiliki 11 indikator yaitu mencapai tujuan strategis dengan mendapatkan target di pasar, mencapai tujuan strategis dengan meningkatkan kesadaran produk/ perusahaan, mencapai tujuan strategis dengan menanggapi tekanan persaingan, mencapai 
tujuan strategis dengan meningkatkan pangsa pasar perusahaan kami, mencapai tujuan strategis dengan meningkatkan profitabilitas, mencapai target pertumbuhan penjualan ratarata dan profitabilitas selama lima tahun terakhir, memiliki kemampuan untuk mencapai strategi promosinya, memiliki kemampuan untuk mencapai strategi pemasaran dan perdagangannya, memiliki kemampuan untuk mencapai strategi keuangan dan pelanggannya, memiliki kemampuan untuk mencapai strategi distribusinya, dan memiliki kemampuan untuk mencapai strategi jaringan pasokannya. Variabel kinerja bisnis (Hutayan, 2019) memiliki 7 indikator yaitu target pasar, profitabilitas perusahaan, kualitas produk, posisi pasar, volume penjualan, produktivitas karyawan, dan pertumbuhan pasar. Pada penelitian ini menggunakan skala Likert dimana terdapat jawaban sangat tidak setuju (STS), tidak setuju (TS), netral (N), setuju (S), dan sangat setuju (SS). Analisis data yang digunakan dalam penelitian ini adalah pendekatan Partial Least Square (PLS) dengan menggunakan bantuan software SmartPLS

\section{HASIL ANALISIS DATA}

Untuk mengukur nilai convergent validity dapat diukur melalui nilai average variance extracted (AVE). Menurut Supranto dan Limakrisna (2019) pada average variance extracted (AVE) nilai yang diharapkan $>0,5$. Sedangkan dalam loading factor nilai yang diharapkan $>$ 0,7 tetapi untuk penelitian dengan model tertentu nilai antara 0,5 hingga 0,6 dapat diterima. Berdasarkan hasil pengujian loading factor tersebut, semua indikator dinyatakan valid.

Tabel 1. Hasil Average Variance Extracted (AVE)

\begin{tabular}{|c|c|c|}
\hline Variabel & AVE & Keterangan \\
\hline Orientasi Kewirausahaan & 0,535 & Valid \\
\hline Orientasi Pasar & 0,706 & Valid \\
\hline Strategi Bisnis & 0,625 & Valid \\
\hline Kinerja Bisnis & 0,513 & Valid \\
\hline
\end{tabular}

Selanjutnya hasil pengujian pada analisis reliabilitas pada penelitian ini dapat dilihat pada Tabel 2 dimana nilai nilai composite reability > 0,6 berarti konstruksi memiliki reliabilitas yang baik. Sama halnya dengan cronbach's alpha, jika nilai yang dihasilkan cronbach's alpha > 0,6 maka variabel dinyatakan reliabel (Supranto dan Limakrisna,2019).

Tabel 2. Hasil Analisis Reliabilitas

\begin{tabular}{|c|c|c|c|}
\hline Variabel & $\begin{array}{c}\text { Composite } \\
\text { Reability }(\boldsymbol{C R})\end{array}$ & $\begin{array}{c}\text { Cronbach's } \\
\text { Alpha }\end{array}$ & Keterangan \\
\hline $\begin{array}{c}\text { Orientasi } \\
\text { Kewirausahaan }\end{array}$ & 0,926 & 0,912 & Reliabel \\
\hline Orientasi Pasar & 0,906 & 0,862 & Reliabel \\
\hline Strategi Bisnis & 0,948 & 0,939 & Reliabel \\
\hline Kinerja Bisnis & 0,880 & 0,840 & Reliabel \\
\hline
\end{tabular}

Berdasarkan pengujian inner model, data yang sudah valid dan reliable akan diolah menggunakan uji koefisien determinasi $\left(\mathrm{R}^{2}\right)$, effect size $\left(\mathrm{f}^{2}\right)$, pengukuran $\mathrm{q}$-square $\left(\mathrm{Q}^{2}\right)$ dimana dapat dilihat pada Tabel 3, Tabel 4, dan Tabel 5 di bawah. Sedangkan hasil pengujian hipotesis 
(path coeffients) dapat dilihat pada Tabel 7. Kemudian hasil uji kecocokan model atau goodness of fit (GoF) dalam penelitian ini memiliki hasil perhitungan sebesar 0,614 maka dapat dikatakan bahwa model penelitian ini memiliki kecocokan yang tergolong besar.

\section{Tabel 3. Hasil Koefisien Determinasi}

\begin{tabular}{|c|c|}
\hline Variabel & $\boldsymbol{R}$ Square \\
\hline Kinerja Bisnis & 0,636 \\
\hline
\end{tabular}

Berdasarkan data pada Tabel 3 di atas menjelaskan bahwa nilai $r$ square dalam penelitian ini adalah sebesar 0,636. Dimana menjelaskan bahwa sebesar 63,6\% dari variabel kinerja bisnis dapat dijelaskan oleh orientasi kewirausahaan, orientasi pasar, dan strategi bisnis, sedangkan 36,4\% dari variabel kinerja bisnis dipengaruhi oleh variabel di luar tiga variabel independen yang sudah diteliti.

Tabel 4. Hasil Effect Size $\left(\mathbf{f}^{2}\right)$

\begin{tabular}{|c|c|}
\hline & Kinerja Bisnis \\
\hline Orientasi Kewirausahaan & 0,067 \\
\hline Orientasi Pasar & 0,064 \\
\hline Strategi Bisnis & 0,539 \\
\hline
\end{tabular}

Berdasarkan data pada Tabel 4 dapat dijelaskan bahwa nilai effect size dalam variabel orientasi kewirausahaan terhadap kinerja bisnis sebesar 0,067 , variabel orientasi pasar terhadap kinerja bisnis 0,064 , dan variabel strategi bisnis terhadap kinerja bisnis sebesar 0,539. Hasil 0,539 memiliki pengaruh yang kuat dan hasil 0,067 memiliki pengaruh yang sedang, dan hasil 0,064 memiliki pengaruh yang lemah.

Tabel 5. Hasil Pengukuran Q-Square $\left(Q^{2}\right)$

\begin{tabular}{|c|c|c|c|}
\hline Variabel & SSO & SSE & $\mathbf{Q}^{\mathbf{2}}$ (=1-SSE/SSO) \\
\hline $\begin{array}{c}\text { Orientasi } \\
\text { Kewirausahaan }\end{array}$ & 1100,000 & 1100,000 & \\
\hline Orientasi Pasar & 400,000 & 400,000 & \\
\hline Strategi Bisnis & 1100,000 & 1100,000 & \\
\hline Kinerja Bisnis & 700,000 & 483,373 & 0.309 \\
\hline
\end{tabular}

Berdasarkan data pada Tabel 5, diketahui bahwa variabel orientasi pasar, orientasi kewirausahaan, serta strategi bisnis memiliki pengaruh sebesar 0,309 terhadap kinerja bisnis. Menurut Supranto dan Limakrisna (2019), apabila nilai q-square di atas 0,15 maka dapat dikategorikan bahwa variable independent memiliki pengaruh kategori sedang terhadap variabel dependennya. Maka dapat disimpulkan dengan angka $Q$-Square sebesar 0,309 dapat dikatakan variabel independen memiliki pengaruh yang sedang terhadap variabel dependen. 
Tabel 6. Hasil Path Coefficients

\begin{tabular}{|l|c|c|c|}
\hline & Original Sample & $t$ - Statitics & P Values \\
\hline $\mathrm{OK} \longrightarrow \mathrm{KB}$ & 0,213 & 2,300 & 0,022 \\
\hline $\mathrm{OP} \longrightarrow \mathrm{KB}$ & 0,186 & 2,093 & 0,037 \\
\hline $\mathrm{SB} \longrightarrow \mathrm{KB}$ & 0,545 & 6,378 & 0,000 \\
\hline
\end{tabular}

Berdasarkan Tabel 6. hasil pengujian pada variabel orientasi kewirausahaan terhadap kinerja bisnis yang merupakan Ha1 pada penelitian ini, menunjukkan nilai original sample sebesar 0,213, $t$-statistics sebesar 2,300 atau lebih besar dari 1,96, dan P Values sebesar 0,022 atau lebih kecil dari 0,05. Dari hasil tersebut dapat disimpulkan bahwa orientasi kewirausahaan memiliki pengaruh positif dan signifikan terhadap kinerja bisnis. Sedangkan, hasil pengujian pada variabel orientasi pasar terhadap kinerja bisnis yang $\mathrm{H}_{2}$ pada penelitian ini, menunjukkan nilai original sample sebesar 0,186, $t$-statistics sebesar 2,093 atau lebih dari 1,96, dan $P$-Values sebesar 0,037 atau lebih kecil dari 0,05. Dari hasil tersebut dapat disimpulkan bahwa orientasi pasar memiliki pengaruh positif dan signifikan terhadap kinerja bisnis. Hasil pengujian pada variabel strategi bisnis terhadap kinerja bisnis yang $\mathrm{H}_{3}$ pada penelitian ini, menunjukkan nilai original sample sebesar 0,545, $t$-statistics sebesar 6, 378 atau lebih dari 1,96 dan P-Values sebesar 0,000 lebih kecil dari 0,05. Dari hasil tersebut dapat disimpulkan bahwa strategi bisnis terhadap kinerja bisnis memiliki pengaruh positif dan signifikan terhadap kinerja bisnis.

Berdasarkan Tabel 1 di atas dapat diketahui nilai dari masing-masing AVE terkait tiap variabel, sehingga dapat diperhitungkan dengan cara:

$$
\begin{aligned}
& \operatorname{AVE} \frac{0,535+0,706+0,625+0,513}{4}=0,594 \\
& R^{2}=0,636
\end{aligned}
$$

Maka,

$$
\begin{aligned}
& \text { GoF }=\sqrt{\text { AVE x R }} \text { R }^{2} \\
& \text { GoF }=\sqrt{0,594 \times 0,636}=0,377
\end{aligned}
$$

Berdasarkan hasil perhitungan Goodness of Fit (GoF) di atas sebesar 0,377 maka dapat dikatakan bahwa model penelitian ini memiliki kecocokan yang tergolong besar. Menurut Tenenhaus (2005) nilai GoF dikatakan besar jika nilainya adalah 0,36, maka dengan hasil penelitian sesuai dengan perhitungan GoF di atas dengan nilai 0.377 termasuk memiliki kecocokan yang tergolong besar.

\section{DISKUSI}

Hasil dari pengujian variabel orientasi kewirausahaan terhadap kinerja bisnis UMKM bidang kuliner di Jakarta Barat memiliki nilai $t$-statistics sebesar 2,300 atau lebih dari 1,96 dan memiliki nilai $P$-Values sebesar 0,022 atau lebih kecil dari 0,05 . Sehingga dapat disimpulkan bahwa variabel orientasi kewirausahaan berpengaruh terhadap kinerja bisnis dalam penelitian ini memiliki arah yang positif dan signifikan. Hal ini pun selaras dengan penelitian yang dilakukan oleh Buli (2017) yang mana hasil penelitian ini menunjukkan bahwa dengan orientasi kewirausahaan yang baik, perusahaan terdorong untuk lebih berani mengambil risiko, berinovasi, dan proaktif dalam menyiapkan strategi untuk melawan pesaing. Sehingga sudah teruji dan dapat dikatakan bilamana orientasi kewirausahaan berpengaruh secara positif dan signifikan terhadap kinerja bisnis. Hasil ini juga sesuai dengan penelitian yang dilakukan oleh 
Kevin dan Puspitowati (2020) dimana penelitian tersebut mengatakan bahwa orientasi kewirausahaan mempunyai pengaruh yang signifikan terhadap kinerja. Dengan adanya orientasi kewirausahaan yang diterapkan dalam suatu usaha maka dapat memungkinkan usaha tersebut dapat terus berkembang dan bersaing dengan pesaing lainnya. Hasil ini juga sesuai dengan penelitian yang dilakukan oleh Smart dan Conant (1994), Wiklund dan Shepherd (2005) dimana penelitian tersebut mengatakan bahwa orientasi kewirausahaan mempunyai pengaruh yang signifikan terhadap kinerja

Hasil dari pengujian variabel orientasi pasar berpengaruh terhadap kinerja bisnis UMKM bidang kuliner di Jakarta Barat memiliki nilai $t$-statistics sebesar 2,093 atau lebih dari 1,96 dan memiliki nilai $P$-Values sebesar 0,037 atau lebih kecil dari 0,05 . Sehingga dapat disimpulkan bahwa variabel orientasi pasar terhadap kinerja bisnis dalam penelitian ini memiliki arah yang positif dan signifikan. Hasil ini sesuai dengan penelitian Naver \& Slater (1990) yang menyatakan bahwa orientasi pasar berpengaruh positif dan signifikan terhadap kinerja bisnis. Orientasi pasar berpotensi meningkatkan kinerja bisnis dan orientasi pasar yang terdiri dari tiga komponen perilaku yaitu orientasi pelanggan, orientasi pesaing dan koordinasi fungsional merupakan budaya perusahaan yang membawa pada meningkatnya pasar. Orientasi pasar berpotensi meningkatkan kinerja bisnis dan orientasi pasar yang terdiri dari tiga komponen perilaku yaitu orientasi pelanggan, orientasi pesaing dan koordinasi fungsional merupakan budaya perusahaan yang membawa pada meningkatnya pasar. Perusahaan dengan orientasi pasar akan menjadikan permintaan pasar, kebutuhan pelanggan sebagai dasar pengambilan keputusan sehingga kinerja bisnis akan meningkat. Hasil ini juga sesuaai dengan penelitian Manahera et al., (2018) yang menyatakan bahwa orientasi dapat meningkatkan kinerja pada UMKM. Hasil yang sama juga ditemukan oleh Sondra dan Widjaja (2020) yang menunjukkan bahwa orientasi pasar memiliki pengaruh yang signifikan terhadap kinerja perusahaan. Perusahaan harus terus meningkatkan kepuasan pelanggan sehingga tujuan perusahaan dapat tercapai. Selain itu perusahaan juga harus tetap memantau tingkat komitmen untuk melayani kebutuhan pelanggan dan menjalankan strategi perusahaan untuk keunggulan kompetitif didasarkan pada pemahaman perusahaan tentang kebutuhan pelanggan serta mendorong keyakinan tentang bagaimana perusahaan dapat menciptakan nilai yang lebih besar bagi pelanggan.

Hasil dari pengujian strategi bisnis berpengaruh terhadap kinerja bisnis UMKM bidang kuliner di Jakarta Barat memiliki nilai t-statistics sebesar 6,378 atau lebih dari 1,96 dan memiliki nilai P-Values sebesar 0,000 atau lebih kecil dari 0,05. Sehingga dapat disimpulkan bahwa variabel strategi bisnis terhadap kinerja bisnis dalam penelitian ini memiliki arah yang positif dan signifikan. Hasil ini sesuai dengan Tjahyuni Murdijaningsih (2012) yang menyatakan bahwa strategi bisnis berpengaruh positif dan signifikan terhadap kinerja bisnis. Hasil ini juga sejalan dengan penelitian Mahmud \& Anomsari (2011) dan Suci (2011) yang menyatakan bahwa strategi bisnis mempunyai pengaruh yang signifikan terhadap kinerja usahanya.

\section{KESIMPULAN}

Berdasarkan hasil analisis data dan dilakukan pembahasan di atas, maka kesimpulan dari penelitian ini yaitu orientasi kewirausahaan, orientasi pasar, strategi bisnis memiliki pengaruh positif dan signifikan terhadap kinerja bisnis UMKM bidang kuliner di Jakarta Barat. Selain itu terdapat saran yang sekiranya dapat bermanfaat bagi pelaku UMKM bidang kuliner di Jakarta Barat, maupun bagi penelitian sejenis. Penelitian selanjutnya, disarankan untuk menambah variabel mediasi seperti kompetensi strategi, keunggulan bersaing, latar belakang 
pendidikan yang kemungkinan akan mempengaruhi kinerja bisnis. Selain itu, disarankan untuk meneliti variabel orientasi kewirausahaan pada UMKM bidang lain, seperti bidang kecantikan.

\section{DAFTAR PUSTAKA}

CNN Indonesia. (2020). Retrieved from www.cnnindonesia.com/ekonomi/20200626123545297-517786/menyelamatkan-umkm-menyelamatkan-ekonomi-indonesia.

Garson, G. D. (2016). Partial Least Square: Regession and Structural Equation Models. Statistical Associates Publishers.

Kevin, \& Puspitowati, I. (2020). Pengaruh Penggunaan Media Sosial dan Orientasi Kewirausahaan terhadap Kinerja UMKM. Jurnal Manajerial dan Kewirausahaan, 2(3), 612-620.

Kompas. (2020). Retrieved from https://money.kompas.com/read/2020/02/15/190000026/tipsusaha-kuliner-yang-bikin-laris-dan-untung?page=all

Kurnia, D., Yaspita, H., \& Yulianda, A. (2020). Manajemen Kewirausahaan. Yogyakarta: Deepublish

Malhotra, N. K. (2015). Essential of Marketing research. Pearson Education Limited

Nadhar, M., Tawe, A., \& Parawansa, D. A. (2017). The Effect of Work Motivation and Entrepreneurship Orientation on Business Performance through Entrepreneurial Commitments of Coffee Shops in Makassar. Econ Journal, 7(1), 470-474.

Nasrudin, J. (2019). Metodologi Penelitian Pendidikan. PT Panca Terra Firma

Suriyanti, H. L., \& Binangkit, D. I. (2019). Peran Kebijakan Pemerintah Dalam Memoderasi Pengaruh Strategi Bisnis Terhadap Kinerja Usaha (Studi Kasus Pada UMKM Bidang Makanan dan Minuman di Kota Pekanbaru). Jurnal Akutansi dan Ekonomika, 9(1), 120128.

Syariati, Rosalina, Azriani, \& Iqbal. (2013). Balance Scorecard. Malang: Ub Press.

Widjaja, O. H., \& Sondra, T. C. (2021). Pengaruh Orientasi Pasar, Orientasi Kewirausahaan, dan inovasi Terhadap Kinerja Usaha UKM Bidang Konveksi di Jakarta Barat. Jurnal Manajerial dan Kewirausahaan, 3(2), 500-508.

Yuliana, R., \& Pujiastuti, Y. (2018). Orientasi Kewiraushaan, Orientasi Pasar, dan Strategi Bisnis terhadap Kinerja Bisnis (Studi kasus pada UMKM di Semarang). Tirtayasa Ekonomika, 13(2), 320 